\title{
Erratum to: Endovascular Treatment of Delayed Type 1 and 3 Endoleaks
}

Peter A. Naughton • Manuel Garcia-Toca •

Heron E. Rodriguez • Aoife N. Keeling •

Scott A. Resnick • Mark D. Morasch •

Mark K. Eskandari

Published online: 16 December 2010

(C) Springer Science+Business Media, LLC and the Cardiovascular and Interventional Radiological Society of Europe (CIRSE) 2010

Erratum to: Cardiovasc Intervent Radiol

DOI 10.1007/s00270-010-0020-y

Mark D. Morasch, the second senior author, is missing from the published article. This erratum shows the correct list of authors.

The online version of the original article can be found under doi:10.1007/s00270-010-0020-y.

P. A. Naughton - M. Garcia-Toca - H. E. Rodriguez

M. D. Morasch · M. K. Eskandari (ه)

Division of Vascular Surgery, Northwestern University Feinberg

School of Medicine, 676 N St. Clair Street, \#650, Chicago,

IL 60611, USA

e-mail: meskanda@nmh.org

A. N. Keeling · S. A. Resnick

Department of Radiology, Northwestern University Feinberg

School of Medicine, 676 N St. Clair Street, \#650, Chicago,

IL 60611, USA 